\title{
Quality-of-Life (QoL) of Indonesian Children Living with HIV: The Role of Caregiver Stigma, Burden of Care, and Coping
}

This article was published in the following Dove Press journal: HIVIAIDS - Research and Palliative Care

\author{
Azwin Mengindra Putera (D) \\ Irwanto (D) \\ Margarita Maria Maramis (iD) ${ }^{2}$ \\ 'Department of Child Health, Faculty of \\ Medicine, Universitas Airlangga - \\ Dr. Soetomo General Academic Hospital, \\ Surabaya, Indonesia; ${ }^{2}$ Department of \\ Psychiatry, Faculty of Medicine, \\ Universitas Airlangga - Dr. Soetomo \\ General Academic Hospital, Surabaya \\ Indonesia
}

Background: Treatment of children with HIV infection has increased rapidly by increasing the life span of HIV patients from baby to adult. Improving the quality-of-life (QoL) in children living with HIV is a priority of HIV management in children and caregivers of children living with HIV have important roles. Caregiver stigma, caregiver burden, and caregiver coping affect caregivers in treating children living with HIV.

Objective: Analyzing the association of caregiver stigma, caregiver burden, and caregiver coping on QoL of Indonesian children living with HIV.

Methods: Participants in this study were caregivers of Indonesian children living with HIV. Participants were measured for caregiver stigma, caregiver burden, caregiver coping, and QoL of Indonesian children living with HIV. The instrument used in measuring caregiver stigma was people living with HIV/AIDS and caregiver questionnaire, caregiver burden used Zarit Burden questionnaire, caregiver coping used F-COPES questionnaire, and QoL used PedsQL for children aged 2-18 years old. Measurement data were analyzed using logistic regression and independent $\mathrm{t}$ tests with $P<0.05$.

Results: Indonesian children living with HIV in this study had an average age of $7.7 \pm 3.68$ years and average participant age of $40.2 \pm 11.26$ years. All participants stated that Indonesian children living with HIV tend to keep their health status confidential. Most QoL of Indonesian children living with HIV was good $(71.7 \%)$, caregiver stigma value was $21.7 \pm 2.06$, and caregiver burden level was moderate, of $50.9 \%$. However, there was no significant association between caregiver stigma $(\beta=0.064 ; P=0.548)$ and burden level $(\beta=0.058 ; P=0.593)$ on QoL. On the other hand, caregiver coping value was 77.2 \pm 7.30 , and there was a significant association of caregiver coping on QoL $(\beta=-0.196 ; P=0.049)$.

Conclusion: There is an association of caregiver coping on QoL of Indonesian children living with HIV, in which the higher the caregiver coping, the lower the QoL. Meanwhile, there is no significant association of caregiver stigma and burden on QoL of Indonesian children living with HIV.

Keywords: caregiver burden, caregiver coping, caregiver of children living with HIV, caregiver stigma, quality-of-life

\section{Introduction}

The Eastern Europe and Central Asia (EECA) region has an increasing number of patients with human immunodeficiency virus and acquired immune deficiency syndrome (HIV/AIDS) every year. In 2000, an estimated 760,000 adults and children had HIV/AIDS in EECA, and this number increased to 1.3 million in 2012. ${ }^{1}$ In Indonesia, it was reported that, in 2006-2010, there were 53 children with
Putera

Department of Child Health, Faculty of Medicine, Universitas Airlangga -

Dr. Soetomo General Academic Hospital Jalan Mayjend Prof. Dr. Moestopo No. 6-8, Airlangga, Gubeng, Surabaya, East Java 60286, Indonesia

Email azwinmengindraputera@gmail.com 
HIV/AIDS, of which $84.9 \%$ were HIV/AIDS positive parents. $^{2}$ Indonesia is a developing country with 16,964 HIV infected patients, including children. ${ }^{3}$ East Java is a province with the second largest population in Indonesia, where Surabaya had the largest red-light district in Southeast Asia, which contributed to the number of children with HIV/AIDS. A recent study found that the number of HIV/AIDS cases in Indonesian children aged 0-4 years was 427 cases in East Java, Indonesia. ${ }^{4}$

Treatment of children with HIV infection has increased rapidly by increasing the life span of HIV patients from baby to adult, and become a medical chronic problem. Problems that are often occurring in children with HIV are social stigmatization, low self-esteem, inhibiting sexual development, need for regular hospital visits, and repeated periods of school absence. ${ }^{5}$ The stigma attached to caregivers of children with HIV it that many members of the community have negative and inaccurate views about HIV, such as associating it with an immoral act. Although the knowledge of caregivers of children with HIV and access to HIV treatment have increased, mental health problems also occur among caregivers of children with HIV. ${ }^{6}$ This condition puts a burden on the caregiver who cares for children with $\mathrm{HIV},{ }^{7}$ so that coping strategies are needed in living everyday life. ${ }^{8}$ If the caregiver's coping strategy is good, the child's quality-of-life (QoL) will improve, and vice versa. ${ }^{9}$

Improving the quality-of-life of HIV children is the focus of current management of HIV-infected children. QoL data of Indonesian children with HIV and the role of caregivers are still very limited, as most studies focused on the quality-of-life of HIV patients in adults. Based on the description above, researchers were interested in conducting research on QoL of Indonesian children living with HIV and how the role of caregiver stigma, burden of care, and coping affect QoL of children living with HIV.

\section{Methods}

\section{Participants}

The participants of this study were caregivers of Indonesian children living with HIV that included biological caregivers (mother and father), non-biological caregivers (relatives, etc), non-custodian caregivers, and single orphans. Participant inclusion criteria included caregivers of children living with HIV; who had children diagnosed with $\mathrm{HIV}^{10,11}$ in the age range 2-18. Participant exclusion criteria included caregivers of children living with HIV, but their children have opportunistic infection secondary to their HIV infection; caregivers who were unwilling to participate in the study; and children who were not cooperative during data collection, which made the caregiver not focus on providing answers (such as crying children, fussy children, etc.). Participants received an explanation regarding the rights and obligations during the study. In addition, the researchers explained the purpose and benefits of the research to the participant's family or guardian before the researchers asked for voluntary approval to become a participant in the study (informed consent).

\section{Ethical Approval}

This study has obtained a certificate of ethical clearance according to the Declaration of Helsinki from the ethical committee team in Dr. Soetomo General Academic Hospital and Faculty of Medicine Universitas Airlangga ethics Committee (1290/KEPK/VII/2019).

\section{Design and Procedure}

A non-experimental quantitative comparative study was conducted in East Java, Indonesia (Probolinggo City and Surabaya City). This study employed the Slovin formula to calculate the study sample, with reference to previous studies in which the number of samples in the study were 48 parents of children living with $\mathrm{HIV}^{12}$ and 30 caregivers of children living with HIV.$^{13}$ Based on these calculations, 53 caregivers of Indonesian children living with HIV were included by purposive sampling (Figure 1).

This research was carried out after obtaining ethical approval. The research procedure was conducted in the community of HIV-infected Indonesian children who underwent outpatient treatment at Dr. Soetomo General Academic Hospital, Surabaya, Indonesia, and the community of HIV-infected Indonesian children in Probolinggo, Indonesia. Researchers collected data for 6 months (July to December 2019), including identification of participants according to the criteria until data collection. The participant data included demographic characteristics, caregiver stigma, caregiver burden, caregiver coping, and quality-oflife for Indonesian children living with HIV.

\section{People Living with HIVIAIDS and Caregiver}

The caregiver stigma was assessed using a measured scale consisting of nine items that counted perceived HIV stigma associated with people living with HIV/AIDS (PLWHA) and caregiver. The total score of the stigma scale was in the range of $0-27$, with a 4-point scale 


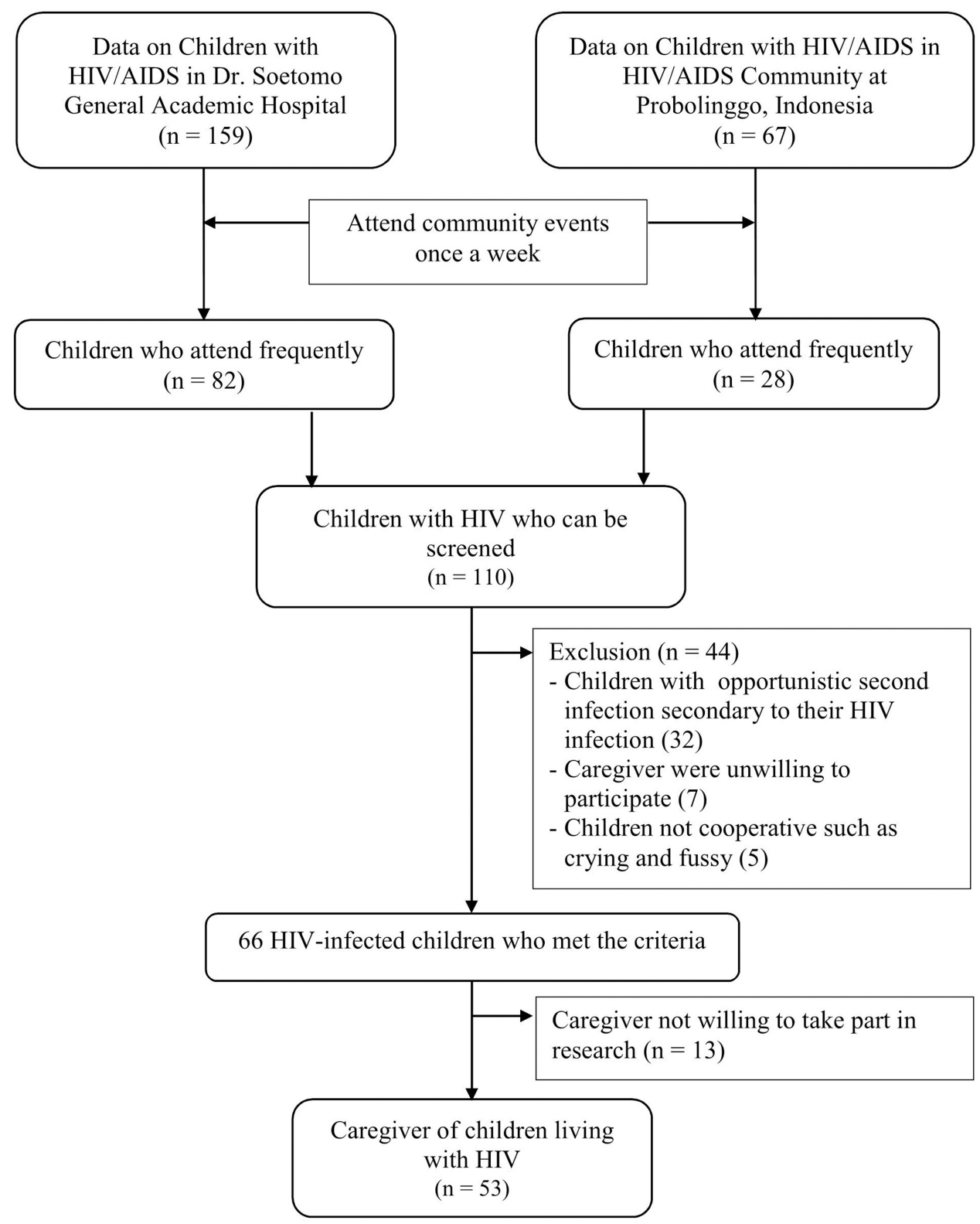

Figure I Process of participant's recruitment.

ranging from strongly disagree (0) to strongly agree (3). The Cronbach's alpha instrument value was 0.89 (PLWHA) and 0.92 (caregiver). ${ }^{14,15}$ Meanwhile, the Indonesian version of PLWHA had validity in the range of $r$ values of $0.538-0.832$ and $\alpha=0.76$ (PLWHA) and 0.82 (caregiver).

\section{Zarit Burden}

Caregiver burden was assessed using Zarit Burden data instruments. This instrument consists of 22 items, which assess five main domains of stress burden, namely health, psychological well-being, financial, social life, and patient relationships. The assessment is based on a 5-point Likert scale, from $0=$ "never" to $4=$ "almost always". The final score ranges from $0-88$, which is grouped into four categories: 0-20 (little or no burden), 21-40 (mild burden), 41-60 (moderate burden), and 61-88 (severe burden). Zarit Burden was declared valid and reliable, with a Cronbach's alpha value of $0.93,{ }^{7,16}$ while the Indonesian version of Zarit Burden was also valid and reliable $(\alpha=0.91){ }^{17}$

\section{Family Crisis Oriented Personal Evaluation Scales} Measurement of caregiver coping used a family crisis oriented personal evaluation scales (F-COPES) questionnaire. The instrument consists of 30-item questions 
designed to assess problem-olving and coping strategies that families use when facing difficult situations. The caregiver assesses a series of coping techniques on five sub-scales; namely acquiring social support, seeking spiritual support, reframing, mobilizing family to acquire and accept help, and passive appraisal. Each sub-scale is assessed with five Likert points based on whether the family is involved in the technique. ${ }^{18}$ F-COPES was declared valid and reliable with Cronbach's alpha $=0.89 .{ }^{19}$ The Indonesian version of F-COPES was proven to be valid and reliable in a previous study. ${ }^{20}$

\section{Quality-of-Life}

Measurement of the QoL of children with HIV used a pediatric quality-of-life inventory (PedsQL) for age range $2-18$ years, which is a questionnaire used to evaluate the health-related quality-of-life (HRQoL) in children. PedsQL is a general health instrument consisting of 23 items that assess five health domains (physical function, emotional function, psychosocial function, social function, and school function) in children and adolescents aged 2 to 18. There are 23 questions that include physical functions (8 items), emotional functions (5 items), social functions (5 items), and school functions (5 items). The assessment of response of each question is based on a 5-point Likert scale: never (0), almost never (1), sometimes (2), often (3), and almost always (4). Scores are transformed to a scale of $0-100(0=100 ; 1=75 ; 2=50 ; 3=25$; and $4=0)$. The total score of 23 items is the average of all answers. The value was good if $\geq 70$. This study used the Indonesian version of the PedsQL questionnaire that was obtained from the license holder and declared reliable $(\alpha>0.7) .{ }^{21-23}$

\section{Statistical Analysis}

The collected data were analyzed using IBM SPSS Statistics software version 23.0 (IBM Corp., Armonk, NY, USA). The statistical test used a multiple logistic regression test to obtain the effect of caregiver stigma, caregiver burden, and caregiver coping on the QoL of Indonesian children living with HIV. Other analysis included the independent $t$-test or Mann Whitney test to analyze the correlation between the F-COPES sub-items. Statistical tests were significant if $P<0.05$.

\section{Results}

\section{Characteristics of Participants}

The average age of Indonesian children living with HIV that met the inclusion criteria was $7.7 \pm 3.68$ years, with a median value of 7 (3-18) years. Meanwhile, the average participant's age was $40.2 \pm 11.26$ years, with a median value of 38 (20-68) years. The average age of the biological mothers of HIV Indonesian children was $33.8 \pm 5.80$ years, with a median value of 33 (23-48) years. The average age of biological fathers of HIV Indonesian children was $35.6 \pm 7.29$ years, with a median value of 35 (24-63) years (Table 1). Most Indonesian children living with HIV in this study were male (54.7\%), and most had elementary school education (49.1\%) and kindergarten (32.1\%). Most participants were biological parents of Indonesian children living with HIV (64.2\%). Most participants were female (as much as $56.6 \%$ ). Most participants had elementary education (35.8\%), followed by middle school (32.1\%), and high school (28.3\%). Most biological fathers of Indonesian children living with HIV had died (52.8\%), whilst most biological mothers of Indonesian children living with HIV were still alive (56.6\%). All participant stated that all Indonesian children living with HIV tended to keep their health status confidential (Table 2).

\section{Effects of Caregiver Stigma, Caregiver Burden, and Caregiver Coping on the Quality-of-Life of Indonesian Children Living with HIV}

The QoL of Indonesian children living with HIV in this study was generally good (38 children; 71.7\%). The QoL value of Indonesian children living with HIV based on four sub-scales obtained the following results: good physical function (38 children; 71.7\%), good emotional function (39 children; 73.6\%), good social function (47 children; $88.7 \%$ ), and poor school function (28 children; $52.8 \%$; Table 2).

Table I Characteristics of Participants

\begin{tabular}{|l|l|}
\hline Characteristics & Mean士SD (n=53) \\
\hline Child's age & $7.7 \pm 3.68$ \\
Caregiver's age & $40.2 \pm 11.26$ \\
Caregiver stigma & $21.7 \pm 2.06$ \\
\hline Caregiver coping & \\
Total & $77.2 \pm 7.30$ \\
Social support & $13.3 \pm 2.39$ \\
Reframing & $30.1 \pm 4.30$ \\
Spiritual support & $14.2 \pm 2.66$ \\
Family mobilization & $9.6 \pm 3.21$ \\
Passive appraisal & $11.1 \pm 3.75$ \\
\hline
\end{tabular}


Table 2 Characteristics of Participant's Frequency Distribution

\begin{tabular}{|c|c|}
\hline Characteristics & n (\%) \\
\hline \multicolumn{2}{|l|}{ Child's sex } \\
\hline Male & $29(54.7)$ \\
\hline Female & $24(45.3)$ \\
\hline \multicolumn{2}{|l|}{ Child's education } \\
\hline Not attending school & $3(5.7)$ \\
\hline Kindergarten & $17(32.1)$ \\
\hline Elementary school & $26(49.1)$ \\
\hline Junior high school & $5(9.4)$ \\
\hline Senior high school & $2(3.8)$ \\
\hline \multicolumn{2}{|l|}{ Biological father } \\
\hline Live & $22(4 \mid .5)$ \\
\hline Deead & $28(52.8)$ \\
\hline Unknown & $3(5.7)$ \\
\hline \multicolumn{2}{|l|}{ Biological mother } \\
\hline Live & $30(56.6)$ \\
\hline Dead & $22(4 \mid .5)$ \\
\hline Unknown & I (I.9) \\
\hline \multicolumn{2}{|l|}{ Caregiver } \\
\hline Biological parents & $34(64.2)$ \\
\hline Others & $19(35.8)$ \\
\hline \multicolumn{2}{|l|}{ Caregiver's sex } \\
\hline Male & $23(43.4)$ \\
\hline Female & $30(56.6)$ \\
\hline \multicolumn{2}{|l|}{ Caregiver's education } \\
\hline Elementary school & $19(35.8)$ \\
\hline Junior high school & $17(32.1)$ \\
\hline Senior high school & $15(28.3)$ \\
\hline College & $2(3.8)$ \\
\hline \multicolumn{2}{|l|}{ Caregiver's income } \\
\hline High & $13(24.5)$ \\
\hline Low & $40(75.5)$ \\
\hline \multicolumn{2}{|l|}{ Caregiver's burden } \\
\hline None & $0(0.0)$ \\
\hline Mild & $26(49.1)$ \\
\hline Moderate & $27(50.9)$ \\
\hline Heavy & $0(0.0)$ \\
\hline \multicolumn{2}{|c|}{ QoL of Indonesian children living with HIV } \\
\hline \multicolumn{2}{|l|}{ Total } \\
\hline$\geq 70$ & $38(71.7)$ \\
\hline$<70$ & $15(28.3)$ \\
\hline \multicolumn{2}{|l|}{ Physical function } \\
\hline$\geq 70$ & $38(71.7)$ \\
\hline$<70$ & $15(28.3)$ \\
\hline \multicolumn{2}{|l|}{ Emotional function } \\
\hline$\geq 70$ & $39(73.6)$ \\
\hline$<70$ & $14(26.4)$ \\
\hline
\end{tabular}

(Continued)
Table 2 (Continued).

\begin{tabular}{|l|l|}
\hline Characteristics & $\mathbf{n}(\%)$ \\
\hline $\begin{array}{l}\text { Social function } \\
\geq 70\end{array}$ & $47(88.7)$ \\
$<70$ & $6(11.3)$ \\
\hline $\begin{array}{l}\text { School function } \\
\geq 70\end{array}$ & $25(47.2)$ \\
$<70$ & $28(52.8)$ \\
\hline Status of Indonesian children living with HIV & \\
Confidential & $53(100.0)$ \\
No & $0(0.0)$ \\
\hline
\end{tabular}

Abbreviation: QoL, quality-of-life.

The average caregiver stigma was $21.7 \pm 2.06$, with a median value of $22 .^{15-26}$ There was no significant relation between caregiver stigma on the QoL of Indonesian children living with $\operatorname{HIV}(\beta=0.064 ; P=0.548)$, with values of each sub-scale as follows: physical function $(\beta=0.023 ; \quad P=0.845)$, emotional function $(\beta=-0.066$; $P=0.608)$, social function $(\beta=0.007 ; P=0.957)$, and school function $(\beta=0.097 ; P=0.418)$. Measurement of caregiver burden obtained a moderate value of $50.9 \%$, followed by mild category of $49.1 \%$. There was no significant relation between caregiver burden on the QoL of Indonesian children living with HIV $(\beta=0.058 ; P=0.593)$, with values of each sub-scale as follows: physical function $(\beta=0.044$; $P=0.706)$, emotional function $(\beta=0.040 ; P=0.769)$, social function $(\beta=0.151 ; \quad P=0.255)$, and school function $(\beta=0.113 ; P=0.369)$. The results showed no influence of caregiver stigma and caregiver burden on the QoL of Indonesian children with HIV (Tables 2 and 3).

Measurement of caregiver coping obtained an average value of $77.2 \pm 7.30$, with values of each sub-scale as

Table 3 Effects of Caregiver Stigma, Caregiver Burden, and Caregiver Coping on the QoL of Indonesia Children Living with HIV

\begin{tabular}{|l|l|l|l|l|l|l|}
\hline Quality of Life & \multicolumn{2}{l|}{$\begin{array}{l}\text { Caregiver } \\
\text { Stigma }\end{array}$} & \multicolumn{2}{l|}{$\begin{array}{l}\text { Caregiver } \\
\text { Burden }\end{array}$} & \multicolumn{2}{l|}{$\begin{array}{l}\text { Caregiver } \\
\text { Coping }\end{array}$} \\
\cline { 2 - 7 } & $\boldsymbol{\beta}$ & $\boldsymbol{P}$ & $\boldsymbol{\beta}$ & $\boldsymbol{P}$ & $\boldsymbol{\beta}$ & $\boldsymbol{P}$ \\
\hline Total & 0.064 & 0.548 & 0.058 & 0.593 & -0.196 & $0.049 *$ \\
Physical function & 0.023 & 0.845 & 0.044 & 0.706 & -0.076 & 0.487 \\
Emotional function & -0.066 & 0.608 & 0.040 & 0.769 & -0.256 & $0.042^{*}$ \\
Social function & 0.007 & 0.957 & 0.151 & 0.255 & 0.002 & 0.988 \\
School function & 0.097 & 0.418 & 0.113 & 0.369 & -0.410 & $0.001^{*}$ \\
\hline
\end{tabular}

Note: *Significant $P<0.05$.

Abbreviation: QoL, quality-of-life. 


\section{Caregiver Coping}

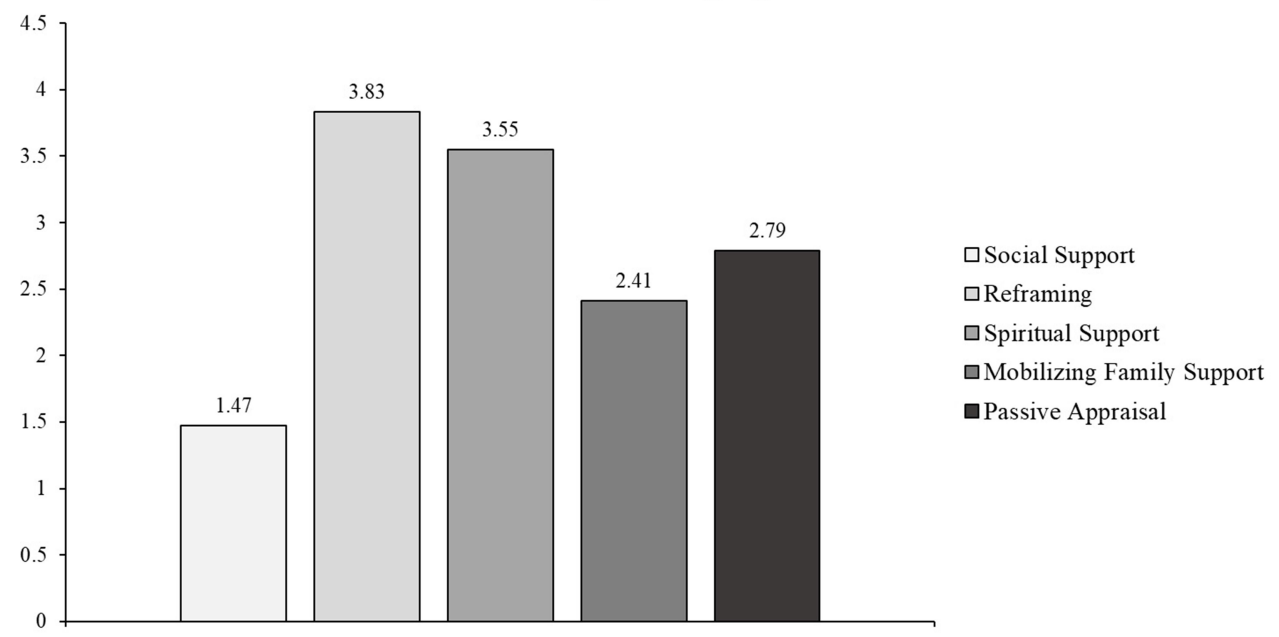

Figure 2 Average score of each caregiver coping sub-scale in caregivers of Indonesian children living with HIV.

follows: social support (13.3 \pm 2.39$)$, reframing (30.1 \pm 4.30 ), spiritual support (14.2 \pm 2.66$)$, family mobilization (9.6 \pm 3.21$)$, and passive appraisal (11.1 \pm 3.75$)$. This study found an effect of caregiver coping on the QoL of Indonesian children living with HIV $(\beta=-0.196$; $P=0.049)$, with value of each sub-scale as follows: physical function $(\beta=-0.074 ; P=0.487)$, emotional function $(\beta=$ $-0.256 ; P=0.042)$, social function $(\beta=0.002 ; P<0.988)$, and school function $(\beta=-0.410 ; P=0.001 ;$ Table 3$)$. These results indicated an influence of caregiver coping with the QoL of Indonesian children living with HIV, in which the higher the value of caregiver coping, the lower the QoL of Indonesian children living with HIV.

The highest score choices in each caregiver coping sub-scale from highest to lowest were reframing (3.8 \pm 0.86 ), spiritual support (3.5 \pm 0.66$)$, passive appraisal (2.8 \pm 0.93$)$, family mobilization $(2.4 \pm 0.80)$, and social support (1.5 \pm 0.27 ) (Figure 2). There was a significant comparison between each caregiver coping sub-scale, including reframing on family mobilization $(t=-8.778$; $P<0.001)$, reframing on social support $(t=-18.924$;
$P<0.001$ ), spiritual support on family mobilization ( $t=$ -7.999; $P<0.001$ ), spiritual support on social support ( $t=$ $-21.033 ; P<0.001$ ), passive appraisal on family mobilization $(t=-2.295 ; P=0.024)$, and passive appraisal on social support $(t=-9.882 ; P<0.001$; Table 4$)$.

\section{Discussion}

This study found a significant relationship between family coping and the QoL of children with HIV. Previous studies mentioned that coping of families with HIV children tended to have psychological disorders (such as excessive stress, depression, and anxiety). This condition affects the QoL of children with HIV because family members with HIV depend on family coping in dealing with various stressors associated with HIV. ${ }^{24}$ Another study stated that coping has a significant relationship with QoL in HIV patients, where the coping self-distraction subscale had a significant positive correlation with the psychological, environmental, and spiritual quality —of life subscale, religion, and personal beliefs. The active coping subscale had a significant correlation to the psychological quality-of-life

Table 4 Comparison of Caregiver Coping Sub-Scale Between Emotion-Focused Coping and Problem-Focused Coping

\begin{tabular}{|c|c|c|c|c|c|c|}
\hline \multirow[t]{3}{*}{ Problem-Focused Coping } & \multicolumn{6}{|c|}{ Emotion-Focused Coping } \\
\hline & \multicolumn{2}{|c|}{ Reframing } & \multicolumn{2}{|c|}{ Spiritual Support } & \multicolumn{2}{|c|}{ Passive Appraisal } \\
\hline & $t$ & $P$ & $t$ & $P$ & $t$ & $P$ \\
\hline Family mobilization & -8.778 & $0.000^{* *}$ & -7.999 & $0.000 * *$ & -2.295 & $0.024^{*}$ \\
\hline Social support & -18.924 & $0.000^{* *}$ & -21.033 & $0.000 * *$ & -9.882 & $0.000 * *$ \\
\hline
\end{tabular}

Notes: *Significant $P<0.05 ; * *$ Significant $P<0.001$. 
subscale. Meanwhile, the emotional support coping subscale had a significant correlation with the social relationship quality-of-life subscale. ${ }^{25}$ Family coping has a significant relationship with the QoL of children with HIV, especially problem-oriented coping, which is often used in overcoming various problems that arise when a patient has HIV. The family is the closest part of HIV patients to a support system in the patient's care process. $^{26,27}$

In this study, caregiver stigma did not have a significant correlation with the QoL of Indonesian children living with HIV. This condition is caused by the emotion focused coping strategy used by caregivers to keep the status of HIV children confidential. So, Indonesian children living with HIV can mingle with communities and does not affect their quality-of-life. This condition is in accordance with several previous studies, where caregivers kept their child's HIV status confidential to avoid negative stigma in society. ${ }^{6,28}$ Another study stated that several participants refused to participate in the study because they were worried that their HIV diagnosis would be revealed. Keeping their HIV status confidential is believed to create positive community stigma against them. ${ }^{29}$ Moreover, other studies also stated that perceived stigma had a significant relationship with quality-of-life, where the higher the level of perceived stigma, the lower the quality-of-life for them. ${ }^{30,31}$

Caregiver burdens in this study did not have a significant relation with quality-of-life of HIV children. This finding is not in accordance with previous studies, which found a significant relationship between caregiver burden and quality-of-life, where the higher the caregiver burden score, the lower the QoL value of HIV patients. ${ }^{31-}$ 33 The difference is possible because the caregiver keeps the health status of children with HIV confidential, ${ }^{34}$ which is psychologically very helpful for the caregiver. ${ }^{7}$ Their social life also does not experience problems despite many economic problems found in HIV cases. ${ }^{35}$ In addition, caregivers do not consider caring for HIV-infected children a burden because it is a routine activity. ${ }^{36}$

There was a significant relationship between family coping subscale and the QoL subscale of children living with HIV. In 58 American families with HIV-infected children, the reframing subscale occupied the highestranking choice followed by passive appraisal, spiritual support, family mobilization, and social support, which ranked lowest. Reframing describes the attitude of passive acceptance, reflecting the tendency to overcome problems in a family without seeking support from others such as friends, extended family, or the community. This condition occurs as many families with HIV-infected children experience exclusion or rejection from the community. Passive appraisal occurs because families feel helpless about their ability to handle their child's medical problems, thus entrusting children's health problems to medical workers. Spiritual support is related to religious beliefs and activities. Many individuals with lifethreatening illnesses attempt to deal with such events in a religious context. This requires collaboration with health workers, especially doctors, to combine understanding of spiritual beliefs with disease management to understand the problem of the illness experienced. ${ }^{37,38}$

Coping strategies used to solve problems vary, namely emotion-focused coping or passive coping and problemfocused coping or active coping. Reframing, spiritual support, and passive appraisal are part of emotion-focused coping, while family mobilization and social support are part of problem-focused coping. ${ }^{8,19}$ Participants in this study had low scores on family mobilization and social support sub-scales, and tended to use emotion-focused coping. Emotion-focused coping is generally adopted when situations are considered uncontrolled and too difficult to handle and resolve. ${ }^{8}$ This emotion-focused coping strategy is most often used by people living with HIV to deal with the disease and its problems. ${ }^{37-39}$

The Social support subscale is rarely used by caregivers and HIV patients. The condition is in accordance with the results of this study, in which caregivers keep their HIV health status confidential. Improper coping strategies have a negative impact on physical and emotional conditions and reduce the QoL of children living with HIV. $^{37,40}$ This research found that caregiver's coping strategies are increasing, thus further reducing QoL, especially on a sub-scale of emotional function and school function in Indonesian children with HIV. This arises because caregivers of HIV-infected children are overprotecting because of very high fears of being exposed to opportunistic infections, bullying, prejudice, discrimination, and future uncertainty of children due to their HIV status. Caregivers also keep the child's HIV status confidential and prevent them from cooperating in their care. ${ }^{39}$ Overprotection causes children's dependence on caregivers, increasing children's emotional problems and negative behavior. These conditions cause risk of delay in children's development, social limitations, cognitive, language, and even neglect, so that 
it interferes with school activities, both interactions with friends and lessons. Parents' feelings of guilt for reducing HIV in children cause excessive total dedication, even routine and leaving work for the care and treatment of children, consequently reducing family income, where the management of HIV-infected children is good for treatment and non-medical treatments such as schools require significant costs. ${ }^{39,41,42}$

Individuals who deal with stress with a problemfocused coping approach are reported to have a much better QoL than those who adopt emotion-focused coping. Several studies have highlighted the importance of social support from various family and non-family elements as problem-focused coping in overcoming problems effectively, reducing stress and improving QoL. ${ }^{8,38}$ In addition, the higher the social support, the higher the QoL of HIV patients. $^{43}$

Coping strategies used by caregivers of children living with HIV appear to be important factors that need to be considered to improve health and QoL of children living with HIV. ${ }^{39}$ An intervention is needed that aims to help caregivers find and utilize appropriate and effective coping strategies, ${ }^{37}$ therefore clinicians must be sensitive to HIV stigma and other specific factors that can disrupt various health support systems. Clinicians must also be ready to provide referrals to communities that support physical and emotional health of HIV children to get various supports that improve family coping, ${ }^{38}$ thereby improving the QoL of children living with HIV. ${ }^{43}$

\section{Conclusions}

Caregiver stigma and caregiver burden do not affect the QoL of Indonesian children living with HIV. There is an influence of caregiver coping strategies on the QoL of Indonesian children living with HIV. The more coping strategies the caregiver has, the lower the QoL of Indonesian children living with HIV, because the caregiver performs a more emotion-focused coping than problemfocused coping.

\section{Abbreviations}

EECA, Eastern Europe and Central Asia; HIV, human immunodeficiency virus; AIDS, acquired immune deficiency syndrome; PLWHA, people living with HIV/ AIDS; F-COPES, family crisis oriented personal evaluation scales; PedsQL, pediatric quality-of-life inventory; HRQoL, health-related quality-of-life.

\section{Acknowledgment}

The authors would like to thank Windhu Purnomo for his technical assistance for this study, in particular the statistical analysis. We would also like to thank Fis Citra Ariyanto who has helped to provide suggestions for reviews of our manuscript and help proofread our manuscript.

\section{Author Contributions}

All authors contributed toward data analysis, drafting and revising the paper, gave final approval of the version to be published and agree to be accountable for all aspects of the work.

\section{Funding}

There is no funding to report.

\section{Disclosure}

Azwin Mengindra Putera, Irwanto and Margarita Maria Maramis declare that they have no conflicts of interest for this work.

\section{References}

1. Fettig J, Swaminathan M, Murrill CS, Kaplan JE. Global epidemiology of HIV. Infect Dis Clin North Am. 2014;28(3):323-337.

2. Evalina R. Studi deskriptif infeksi HIV pada anak di rumah sakit umum pusat adam malik medan. Sari Pediatri. 2012;14(2 (2012)):73-78. doi:10.14238/sp14.2.2012.73-8

3. Ibrahim K, Songwathana P, Boonyasopun U, Francis K. The HIV/ AIDS epidemic in Indonesia: does primary health care as a prevention and intervention strategy work? Int $J$ Nurs Pract. 2010;16(2):87-91. doi:10.1111/j.1440-172X.2010.01816.x

4. Elisanti AD, Suprapti. Study Demografi Penderita HIV-AIDS DiPuskesmas Alun-Alun Gresik. Surya. 2018;10(3):25-29.

5. Cohen S, Ter Stege JA, Weijsenfeld AM, et al. Health-related quality of life in perinatally HIV-infected children in the Netherlands. AIDS Care. 2015;27(10):1279-1288. doi:10.1080/09540121.2015.1050986

6. McHenry MS, Nyandiko WM, Scanlon ML, et al. HIV stigma: perspectives from kenyan child caregivers and adolescents living with HIV. J Int Assoc Provid AIDS Care. 2017;16(3):215-225. doi:10.1177/2325957416668995

7. Ochigbo S, Oparah S, Torty C. Burden of care on caregivers of children infected with human immunodeficiency virus in Calabar, Nigeria. Int J AIDS Res. 2018;5(3):177-180.

8. Kohli R, Sane S, Ghate M, Paranjape R. Coping strategies of HIV-positive individuals and its correlation with quality of life in Pune, India. Int Soc Work. 2016;59(2):256-267. doi:10.1177/ 0020872813519658

9. Sherr L, Skeen S, Hensels IS, Tomlinson M, Macedo A. The effects of caregiver and household HIV on child development: a community-based longitudinal study of young children. Child Care Health Dev. 2016;42(6):890-899.

10. Abdollahi A, Saffar H. The diagnosis of HIV infection in infants and children. Iran J Pathol. 2016;11(2):89-96.

11. Parekh BS, Ou C-Y, Fonjungo PN, et al. Diagnosis of human immunodeficiency virus infection. Clin Microbiol Rev. 2018;32(1):e00064-18. 
12. Lesar S, Maldonado YA. Parental coping strategies in families of HIV-infected children. Child Care Health. 1996;25(1):19-35. doi:10.1207/s15326888chc2501_3

13. Mathilda Z, Mukombwe O, Doreen M, Clara H. Coping strategies of caregivers of HIV/AIDS orphans in ward 15 Bikita District, Masvingo Province, Zimbabwe. Money. 2015;12:57.

14. Liu H, Xu Y, Lin X, Shi J, Chen S, Sullivan PS. Associations between perceived HIV stigma and quality of life at the dyadic level: the actor-partner interdependence model. PLoS One. 2013;8 (2):e55680. doi:10.1371/journal.pone.0055680

15. Liu H, Xu Y, Sun Y, Dumenci L, Seedat S. Measuring HIV stigma at the family level: psychometric assessment of the Chinese Courtesy Stigma Scales (CCSSs). PLoS One. 2014;9(3):e92855-e. doi:10.1371/journal.pone.0092855

16. Seng BK, Luo N, Ng WY, et al. Validity and reliability of the zarit burden interview in assessing caregiving burden. Ann Acad Med Singapore. 2010;39(10):758-763.

17. Afriyeni N, Sartana S. Gambaran tekanan dan beban yang dialami oleh keluarga sebagai caregiver penderita psikotik di rsj prof. h.b. sa'anin padang. Jurnal Ecopsy. 2017;3(3):3. doi:10.20527/ecopsy.v3i3.2671

18. McCubbin HI, Olson DH, Larsen A. Family Crisis-Oriented Personal Evaluation Scales (F-COPES) 1981. 1987.

19. Eaton PM, Davis BL, Hammond PV, Condon EH, McGee ZT. Coping strategies of family members of hospitalized psychiatric patients. Nurs Res Pract. 2011;2011:1-12. doi:10.1155/2011/392705

20. Putera AM, Irwanto I, Maramis MM, Prasetyo RV, Soemyarso NA, Noer MS. Effect of mental health problems on the quality of life in children with lupus nephritis. Neuropsychiatr Dis Treat. 2020;16:1583-1593. doi:10.2147/NDT.S250373

21. Varni JW, Burwinkle TM, Seid M, Skarr D. The pedsQL TM* 4.0 as a pediatric population health measure: feasibility, reliability, and validity. Ambulatory Pediatr. 2003;3(6):329-341. doi:10.1367/15394409(2003)003<0329:TPAAPP > 2.0.CO;2

22. Huang IC, Thompson LA, Chi -Y-Y, et al. The linkage between pediatric quality of life and health conditions: establishing clinically meaningful cutoff scores for the PedsQL. Value Health. 2009;12 (5):773-781. doi:10.1111/j.1524-4733.2008.00487.x

23. Banerjee T, Pensi T, Banerjee D. HRQoL in HIV-infected children using PedsQL 4.0 and comparison with uninfected children. Qual Life Res. 2010;19(6):803-812. doi:10.1007/s11136-010-9643-3

24. Li L, Liang L-J, Ding YY, Ji G. Facing HIV as a family: predicting depressive symptoms with correlated responses. J Fam Psychol. 2011;25(2):202-209. doi:10.1037/a0022755

25. Kamthan S, Pant B, Gupta M, Kumar D, Bansal R, Nasser K. A cross sectional study on quality of life and coping skills of people living with HIV and AIDS in Meerut, UP. Natl J Integr Res Med. 2019;10(2).

26. Friedland J, Renwick R, McColl M. Coping and social support as determinants of quality of life in HIV/AIDS. AIDS Care. 1996;8 (1):15-31. doi:10.1080/09540129650125966

27. Côté J, Delmas P, Delpierre C, Sylvain H, Delon S, Rouleau G. Factors related to quality of life in treatment-adherent, successfully treated HIV patients in France. Open Nurs J. 2009;3:10-17. doi:10.2174/1874434600903010010

28. Chambers LA, Rueda S, Baker DN, et al. Stigma, HIV and health: a qualitative synthesis. BMC Public Health. 2015;15:848.
29. Zhang Y-X, Golin CE, Bu J, Emrick CB, Nan Z, Li M-Q. Coping strategies for HIV-related stigma in Liuzhou, China. AIDS Behav. 2014;18 Suppl 2(0 2):S212-S220.

30. Zarei N, Joulaei H, Fararouei M. Perceived stigma and quality of life among women living with HIV/AIDS. Women's Health Bulletin. 2017;4(1):1-6

31. Kalomo EN, Liao M. Burden of care among caregivers of persons living with HIV/AIDS in rural Namibia: correlates and outcomes. Soc Work Public Health. 2018;33(1):70-84. doi:10.1080/19371918.20 17.1415180

32. Lee SJ, Li L, Jiraphongsa C, Rotheram-Borus MJ. Caregiver burden of family members of persons living with HIV in Thailand. Int J Nurs Pract. 2010;16(1):57-63. doi:10.1111/j.1440-172X.2009.01812.x

33. Chandran V, Madi D, Chowta N, et al. Caregiver burden among adults caring for people living with HIV/AIDS (PLWHA) in Southern India. J Clin Diagn Res. 2016;10(5):OC41-OC43.

34. Osafo J, Knizek BL, Mugisha J, Kinyanda E. The experiences of caregivers of children living with HIV and AIDS in Uganda: a qualitative study. Global Health. 2017;13(1):72. doi:10.1186/ s12992-017-0294-9

35. Kidman R, Thurman TR. Caregiver burden among adults caring for orphaned children in rural South Africa. Vulnerable Child Youth Stud. 2014;9(3):234-246. doi:10.1080/17450128.2013.871379

36. Chauhan RC, Rai SK, Kant S, Lodha R, Kumar N, Singh N. Burden among caregivers of children living with human immunodeficiency virus in North India. $N$ Am J Med Sci. 2016;8(3):129-133. doi:10.4103/1947-2714.179117

37. Martin SC, Wolters PL, Klaas PA, Perez L, Wood LV. Coping styles among families of children with HIV infection. AIDS Care. 2004;16 (3):283-292. doi:10.1080/09540120410001665295

38. Martin S, Calabrese SK, Wolters PL, Walker KA, Warren K, Hazra R. Family functioning and coping styles in families of children with cancer and HIV disease. Clin Pediatr (Phila). 2012;51 (1):58-64. doi:10.1177/0009922811417300

39. Silva R, Rocha V, Davim RMB, Torres G. Ways of coping with AIDS: opinion of mothers with HIV children. Rev Lat Am Enfermagem. 2008;16(2):260-265. doi:10.1590/S0104-116920080 00200014

40. McIntosh RC, Rosselli M. Stress and coping in women living with HIV: a meta-analytic review. AIDS Behav. 2012;16(8):2144-2159.

41. Constantino MC, Ganga ME. The effects of HIV and AIDS on the academic performance of orphaned and vulnerable children from child headed families. Int $J$ Learn Dev. 2004;3(3):41-53. doi:10.5296/ijld.v3i3.3694

42. Betancourt TS, Meyers-Ohki SE, Charrow A, Hansen N. Annual research review: mental health and resilience in HIV/AIDS-affected children: a review of the literature and recommendations for future research. $J$ Child Psychol Psychiatry. 2013;54(4):423-444. doi:10.1111/j.1469-7610.2012.02613.x

43. Diatmi K, Fridari IGAD. Hubungan antara dukungan sosial dengan kualitas hidup pada orang dengan HIV dan AIDS (ODHA) Di Yayasan Spirit Paramacitta. Jurnal Psikologi Udayana. 2014;1(2). doi:10.24843/JPU.2014.v01.i02.p14
HIV/AIDS - Research and Palliative Care is an international, peerreviewed open-access journal focusing on advances in research in HIV, its clinical progression and management options including antiviral treatment, palliative care and public healthcare policies to control viral spread. The manuscript management system is completely online and includes a very quick and fair peer-review system, which is all easy to use. Visit http://www.dovepress.com/testimonials.php to read real quotes from published authors. 